\title{
Understanding Secularism and National Identity in French Political Discourses
}

\author{
Aprillia Firmonasari; Wening Udasmoro; Yohanes Tri Mastoyo \\ Faculty of Cultural Sciences, Universitas Gadjah Mada, Indonesia \\ Corresponding Author: aprillia@ugm.ac.id
}

\begin{abstract}
The concept of secularism or laicité is expressed in political discourses in various ways by the French presidential candidates in the 2017 campaign. Both candidates, Emmanuel Macron (EM) and Marine Le Pen (MLP) used specific forms and lingual expressions to explain secularism and national identity, especially those related to 'Islam', 'immigration' and 'terrorism'. This study uses critical discourse analysis linked to their parties' ideologies based on identity, activities, goals, norms, and values. In the discourses presented by EM and MLP, Islam is associated with religion, Muslims, jihad, Islamic fundamentalists, the burqa, and secularism. The results of discourse analysis show that EM's and MLP's discourses on secularism and Islam are notably different. MLP views secularism in France as being under threat due to external threats, namely immigrants and in particular Muslim immigrants. In contrast, EM views secularism as a concept to support and protect the identity of the nation and to support and to add to the diversity of French culture and identity. The findings of this research is that French concepts of national identities, which is closely related to secularism, correlates to the ideologies of the respective presidential candidates' parties. The relationships between the parties' ideologies, national identities, and discourses investigated in this research can be used as a methodology for political discourses, especially French political discourses.
\end{abstract}

Keywords: Islam; national identity; political parties; presidential campaign; secularism

\section{INTRODUCTION}

Today the emergence of Islam as an iconic, political, socio-cultural, and religious phenomenon has become a public debate in many countries (Grillo, 2004; Mandaville, 2009) including Muslim-majority countries, for example Indonesia during the 2109 presidential campaign. Joko Widodo (Jokowi) who had allianced his party with the Islamic organization Nadlahtul Ulama (NU) embraced the idea of Indonesian Islam known as "Islam Nusantara". Slightly different to NU, Muhammadiyah which is also an Islamic organization, embraces the concept of "Progressive Islam" or "Islam Berkemajuan". In contrast, Prabowo as Jokowi's political opponent, with the support of the Front Pembela Islam (FPI) rejected Islam Nusantara seeking to bring back Islam to "the right path". FPI became the most outspoken critic of the "Islam Nusantara" movement. FPI rejects "Islam Nusantara" because it is similar to "Secularism, Pluralism, and Liberalism", banned by a Majelis Ulama Indonesia (MUI) fatwa since 2005 (Ayuwuragil, 2018; Njoto-Feillard, 2015; Nurita, 2019; Power, 2018)

In contrast, in French political discourse, the discourse on Islam became associated with immigration and terrorism following the 911 incident on 11 September 2001 (Bowen, 2009; Dennison \& Talò, 2017; Dungan, 2018; Koopmans, 2005; Messina, 2006; Triandafyllidou, 2011). Terrorist attacks, including in Bali (2003 and 2005), Madrid (2004), London (2005) and Mumbai (2008) have created concerns among Western countries in considering Islam, including in France, the country that has more than 13\% Muslim population. In addition, France is 
also maintaining a close relationship with an umbrella (a guardian) for Francophone countries, especially for countries in the northern and western parts of African where the majority of the population is Muslim, which includes Morocco, Algeria, Mauritania, Guinea, Ivory Coast, Benin and Burkina Faso. Many people from these African countries, after becoming independent in the 1960s, have emigrated to France (Forsdick, 2018; Munif, 2011). Given this pattern of immigration, Islam and migrants have become a major focus in the French political discourse, moreso after the 2011 terrorist killing of staff at the Charlie Hebdo magazine office, done in retaliation for publishing a caricature of the prophet Muhammad (BBC, 2015; Udasmoro, 2017; Vasilopoulos et al., 2018; Wessler et al., 2016).

The discourses on Islam, found in the social and political domains, are related to French historical developments and cultural context (Raymond, 2009; Silverman, 1992). In political life, the radical republican defines himself as being against the determinism of the past, such as the power of the feudal and Christian ideologies. The republican is a secularist who advocates people live in freedom with a separation of state and religious. The concepts of pluralism and liberalism emphasize the state's role in politically ascendant role. The discourse on secularism has led to a perception, in some sections of the community, that contemporary French society is unable to integrate Muslim minorities, most of whom are immigrants (Allen, 2011; Doyle, 2011; Joppke, 2009; Laurence \& Vaisse, 2006). This perception arises because the French people adhere to the basic principles of the Republic related to French "national identity". The application of the basic principles can create difficulties for the Muslim, mainly immigrants, in their daily lives within the French secular state.

Research on the laicité concept in France in PE Nilsson's work 'Secular Retaliation': A Case Study of Integralist Populism, Anti-Muslim Discourse, and Liberal Discourse on Secularism in Contemporary France" (2015) maps out the main features of French secularism as an identity mode and as a political and social practice. Secularism has become a basic aspect in French political and social life. The perceived assertion of Islamic identity in France has led to a reaction by the left and right wings of political spectrum (Kastoryano \& Upreti, 2006; Nillson, 2015). Continuing Nilsson's research, Scrinzi (2017), in "A "New" National Front: Gender, Religion, Secularism and the French Populist Radical Right", discusses the mobilization of right- and left-wing political communities against "Islamization" in the name of secularism in French society in 2010.
Scrinzi considers catalyst for change in the ideology of right-wing populist groups (Betz, 2004; Lesselier, 1997; Scrinzi, 2017a). Populist parties propound the theme of "anti-immigration" from Muslim countries arguing for example, they are defending the rights of women and gays, or restoring the Christian roots of French society. In political life, especially in the presidential campaign, the right wing parties sought to increase its number of votes and simultaneously legitimize the argument for antiimmigration policies (Larzillière \& Sal, 2011; Scrinzi, 2017a). Right wing party ideologues have contested the policy on Muslim immigrants. This article seeks to examine the French concepts of secularism related to alternative French national identities put forward by the two presidential candidates, Emmanuel Macron (EM) and Marine Le Pen (MLP) in the campaign of 2017.

The debate about national identity and immigrants became a political contest, and arose with France's rejection of the constitutional referendum on the ratification of the European constitution formation agreement in 2005. This rejection was linked to economic problems, the government's failure to create jobs for the population, and some aspects of the constitution that threatened the values of French nationality. At that time, fears began to emerge among the French people, and these resulted in an outpouring of nationalism. Political parties began to change their ideologies, for example right-wing parties that tended to be nationalist began to become xenophobic. Right and left wing parties began to espouse their concepts of national identity. These debates emerged strongly, especially during the 2007 and 2012 presidential campaigns, because at that time the French people's trust in the neo-Gaullist Jacque Chirac government began to decline. As a result, a new generation of presidential candidates emerged such as Nicolas Sarkozy (from the Union pour un Mouvement Populaire - UMP party) and François Holland (from the Parti Social - PS party). The debates of the 2007 and 2012 presidential campaigns, over the concept of national identity, resurfaced in the 2017 presidential campaign between EM and MLP. Debates on immigrant-related problems persisted and its affect on the social and economic life of the French people. In addition, there was a crisis of public confidence in the French political system.

In the 2017 French presidential campaign, narratives regarding immigrant issues, in particular Muslim immigrants, Islam, in relation to secularism were expressed by the candidates, EM and MLP who were selected in the second round. In EM's campaign speech dated February 4, 2017, EM states: La laïcité, c'est un bouclier. Ce n'est une menace pour personne. 
C'est une liberté et une exigence pour tous pour chacun. "Secularism is a shield. Secularism is not a threat to anyone. Secularism is freedom for all and a must for everyone.". In the official website of the political movement La République En Marche (LaRem), EM states that France embraces a secularism that protects the freedom of French citizens. The state's neutrality allows citizens to express their religious beliefs freely and ensure the equality of all citizens in all public services. With regard to Islam, EM promised support for Islamic organizations in France, among others: building places of worship and training mosque imams. In addition, EM also promised to improve the image of Muslims in France which had become synonymous with terrorism (Macron, 2017a).

In contrast to EM, the presidential candidate of the National Front party (FN) argued that Islam was incompatible with French values and its way of life. MLP added that secularism should be maintained to preserve the French national identity. In the presidential debate held at the TF1 television station, MLP several times condemned Islamic fundamentalists, among others, saying on doit expulser les Etrangers Islamistes fichés $S$ "we must expel the Islamic foreigners, as indicated by the S card [people who are deemed as dangerous]", il faut la guerre contre fondamentalisme islamiste, et on doit s'en donner les moyens "we have to fight Islamic fundamentalists and we must do this in various ways", le fondamentalisme islamiste plus ne doit avoir le droit de cité dans notre pays "Islamic fundamentalists may no longer have the right to be citizens in our country". In various statements, it appeared that MLP strongly supported an 'exclusive' Republican model of French culture as the national identity (Atabong, 2018; Gorce, 2017; Reynié, 2016).

From EM's and MLP's ideas mentioned above, it is evident that both have different points of view. The focus of this study then is to examine concepts of secularilsm in relation to Islam from the perspectives of the two presidential candidates in the presidential campaign of 2017. To examine this, two questions are address. Firstly, how did both candidates relate their political ideologies to concepts of secularism and Islam in their campaign political discourses? Secondly, were their concepts of secularism synonymous with identity shifts or just variations of pluralism and liberalism? The data used in this study is from the political discourses of EM and MLP during their 2016 and 2017 presidential campaigns. The discourses analyzed were those containing the two candidates' statements on secularism in relationship to Islam.
These questions are addressed using critical discourse analysis which aims to determine the context of the speech. The transcripts of the candidates' speeches are analysed for lingual markers containing elements of secularism and Islam. Relevant data was collected using the NVIVO software application's coding feature, coding matrix, word frequency, and text query function. In order to analyze the data, ideological schema based on basic categories, such as identity, activities, goals, norms, and values of social groups (in this study the political parties) were used to determine ideologies of the respective candidate. The paper firstly examines secularism in France and how it developed then how the candidates explain secularism and Islam in accordance with their ideologies in their arguments.

\section{DISCUSSION \\ Key Concepts}

Firstly, the meanings of the terms 'secular', 'secularism' and 'secularity' used in this paper will be discussed. The term 'secular' is understood to be the main element of modernity that is used to build and understand secular reality in contradistinction to the metaphysical. Secondly, the term 'secularization' is used to make a distinction between religious and secular or non-religious matters that is, the nation, economy, the arts and entertainment in today's society. Secularization grew as an historical transformation that has changed the concept of primitive societies towards modern secularism, for example the forms of the separation of state and religion in the modern era. In this case, religion is identified as a metaphysical reality, irrational and outdated, while secular is related to positivism. Thirdly, the term 'secularism' refers to a perspective which is manifested in the historical, philosophical or development of state ideologies. Secularism arises from history which has seen the constitutional separation of state and religious powers, the differentiation of cognitive reasoning (eg, science and philosophy as opposed to theology) and the practical (eg, law and morality as opposed to religion) (Baubérot, 2012a; Casanova, 2009; Kuru, 2008; Lægaard, 2017; Modood, 2010; Spickard, 2013). Based on this discussion, how is secularism related to religion and culture in France?

\section{Secular, Secularism and Secularisation: Religion and Culture in France}

Since secularism has evolved from the different historical experiences of different states, the cognitive and practical differentiation, has various forms. In France, secularism 
is based on freedom, in the sense that the state protects a citizens's right to practice a religious belief. Religion is also placed in the private space and not in the public space. Another case is in America, where secularism is interpreted as the separation between church (religion) and state (politics) power. Like France, in the US, religions is in the people's private sphere separated from the political spheres.

This is different to Indonesia, a country where the majority of people profess Islam and where secularism is as a quasi-concept that takes a "middle road" to accommodate Islamic groups that want to achieve hegemony over Indonesia's state ideology as well as secular groups, which are advocating concepts of modernity and progress (Barton, 2010; Elson, 2010).

In France, the concept of the Republic model is based on the principles of universalism and individualism, which means that relations between the State and the individual must exclude intermediary groups. In this case, "religion" and "culture" which is considered as the intermediary and should not interpose itself in that relationship. Thus, laicité or secularism can serve to demarcate state and religious power. Secularism is a central element of the "Republic" model of France. With the principle of secularism, every citizen must exercise restraint in showing characteristics of their culture and religion in public (Portier, 2018; Scrinzi, 2017a).

However, the principle of secularism today is understood to be post-ideological which emphasises French identity construction (Chevrier, 2007; Nillson, 2015). The principle was embraced by right wing political parties that emerged in the late 20th century. With the label of "Christian identity", they wanted to restore France's based on a "Christian cultural heritage" (Baubérot, 2015; Mc Dougall, 2018). On the other hand, sociologists of religion understand secularism as a weakening of church temporal power. They see secularism as part of a social and economic system of the neoliberals. In fact, secularism is seen as a socially constructed at a particular point in history and not as a result of political and social progress.

Then, what is the position of Islam within the European concept of secularism? The presence of Islamic civilization made European nations fearful that it could threaten its Judéo-Christian culture an heritage. They feared that Islamic values could damage and even replace their "Western" values (Akan, 2009). Furthermore, according to Mc Dougall (2018), the concept of Islam in various studies of the sociology of religion over recent decades is described as an outdated concept, as opposed to secular modernity with its separation of church and state.
During the twentieth century, secularism in the Republic of France was seen to be reconciled with Catholic, Christian, even Jewish. All three religions had been forced to conduct its affairs within a secularist political system, but not so with Islam.

In France, Islam was called "French Islam" because it combined the principles of the secular Republic with manifestations practices drawn from the French understanding of Moroccan Islamic orthodoxy (N. Davidson, 2012; Forsdick, 2018). This designation is further elaborated by French political, social scientists, officials in the years around the First World War. The concept of a "French Islam" is still used to understand Islam in metropolitan France, although it is different from the Islam practised by immigrants. To cite Muslim immigrants, the French state simply uses the term "Islam", not "French Islam". Why is that? The term "Islam" is associated with the immigrant and with physical rituals, while the term "Muslim" is only considered as a marker of difference along gender and race lines (M. del G. Davidson, 2018; Kuru, 2008). The use of various descriptors with 'Islam' is indeed a phenomenon found in various countries. For example, in Indonesia, the majority of people who embrace Islam recognize various classifications of Muslims related to place, including "Nusantara Islam", "Indonesian Islam", "Javanese Islam", and "Sasak Islam" (Qomar, 2015). The diversity of identities represented by these terms show that "Islam" is related to cultural practices carried out by its adherents belonging to various communities with different racial, ethnic, and national backgrounds, social classes, genders and so on.

In France, there has been racial discrimination against immigrants living in the suburbs who have became victims of cultural and social intolerance. The controversy over the issues on the use of religious symbols in the past 15 years, for example the use of hijab by female students in schools, placed strict limits on the recognition of religious and cultural practices in the French Republic. It has overshadowed and led to refocusing on the ideal form of the Republic. For this reason, it became necessary to reaffirm laïcité values, reemphasise the 1905 law (the law of separation between church and state) with adjustments to today's multicultural society. Due to the various concerns problems related to the position of Islam in society, in 2003, President Jacques Chirac asked Bernard Stasi, a politician from the central axis party to form a commission in order to formulate the application of secularism in the Republic of France. The commission proposed a social secularism as a way to combat discrimination against Muslim 
immigrants. Furthermore, Haute Autorité de Lutte contre les Discrimination et pour l'Egalité was established as a 'commission against discrimination and for equality' to investigate discrimination cases (Baubérot, 2012b). The Stasi report also states that laïcité is at the core of the French Republic that contains the principles of collective life and guarantees individual and state rights and obligations. Laïcité contains three inseparable values, namely: freedom, equality before law in every spiritual and religious choice, and neutrality of political power. The Stasi commission was disbanded in 2011, and turned into a new institution, le Défenseur des Droits 'Human Rights Defender' (Blanchot-Isola, 2017; Teitgen-Colly, 2011).

The four characteristics of French secularism, namely: separation, neutrality, freedom and equality, as noted above were not well received in the community. The four characteristics were perceived as emerging threats in the country because of their neutrality and was contrary to the 1905 law. Additionally, the principle of separation, freedom, and equality were not well developed. Most of the French people believe that the greatest threat comes from the manifestation of religious expression in the public sphere for example, by the use of the full-face veil practised by some Muslim women. This is believed by some observers in France to be the end of the supremacy of the greatness of the West (Baubérot, 2012b; Doyle, 2011; Lamine, 2006; Werbner, 2007). These threats perceived by the French public in turn influenced political life. EM and MPL, along with other politicians, began to create discourses on the national identity during the presidential campaign in 2017. The following section explains French national identities represented in the ideologies and programs of the $L a$ République en Marche party (hereinafter abbreviated as LaRem - the party of EM) and the Front Nasional party (hereinafter abbreviated as FN - the party of MLP).

\section{Secularism and Islam from the Ideological Perspectives of La Republique en Marche (LaRem) and Front National (FN)}

The presidential campaign in 2017 was one of the most important political events since the beginning of presidential elections because of the differences with previous campaigns in France. For the first time in the history of the Fifth Republic of France, two candidates of the main parties did not qualify in the first round. Candidates who advanced to the second round were EM from the LaRem party (central axis) and MLP from the FN party (far right wing). The result for both parties was unprecedented. EM's victory, with $66.1 \%$ of the votes compared to MLP's 33.9\%, through a newly formed party founded one year before the actual campaign. The found of this party had been widely predicted by political observers. EM's social policy was much more progressive than MLP. EM had a more liberal attitude towards immigration, particularly for immigrants from the Middle East and Africa because he believed that immigration would bring positive effects for the economy (Dragvigny, 2017; Hewlett, 2017; Macron, 2017c). According to the LaRem movement this policy was representative of the moderate left and the moderate right factions to fight the far right and far left parties. LaRem preferred to call itself the "political movement" instead of a "political party" as its formation was not based on political ideological principles, such as republicanism and socialism, rather it was based on equality and a desire to overcome divisions (Elgie, 2018). According Delaurens (2018) the mention of the "movement" instead of a "party" was a political revolution as it aspired to make reforms to the state. In addition, a split in the major political parties, such as the Socialist Party (PS), positioned LaRem to become a political movement that could attract the majority of French voters.

Unlike the other political parties that already had an ideological basis, as the name suggests LaRem or En Marche ('on the move'), the establishment of this movement started by canvassing public opinion of France in order to formulate its own political principles and advance the nation. Its difference with other political parties is more in the nature of renovation de l'engagement politique 'reform of political commitment' (LaRem Official Website).

By adopting a centrist principle, LaRem has a dualistic political conception. Regarding centrism, Duverger (date?) argues that political competition always takes place between the left and right wings. At the same time, there may be a centrist party which unites moderate right and left under one policy umbrella and leaves aside the extreme right and left. Duverger believes that in France, moderate elements of the left and right have split from the far left and right wings which have opposing political ideologies. Duverger's assumption is proven by the emergence of LaRem and the election of EM as French president in 2017 (Duverger, 1951, 1964, 1965, 1967). Larem which was drawn from the moderates means an evolution of existing power relations rather than revolution. Since the establishment of LaRem, the values contained in this movement was known already, namely liberal and pro-European (Bugeau, 2017; Delaurens, 2018; Weber, 2017). 
Regarding secularism and its relationship to Islam, EM and his movements advocated tolerance. In his speech in Montpellier in 2017, EM told the history of wars between Protestants and Catholics in the Middle Ages. Reflecting on the attitude of King Henry IV who reconciled the conflict between Protestants and Catholics, EM argued that these conflicts should not be repeated. Therefore, tolerance is the most important approach, it means: the public must respect the religion professed by each individual, including Muslims. Although Islam is currently a topic of concern in France, EM argued that no religion is wrong, and all religions are equal. Laïcité or secularism is not intended to fight or restrain a religion, but instead to support freedom of religion, although strictly within the legal framework. However, there was one controversial statement from EM when addressing a speech in Montpellier on October 18, 2016 (Saurel, 2016a):

Notre mission, elle sera difficile, elle prendra du temps, elle sera exigeante avec toutes et tous. Ce sera de faire que les Français de confession musulmane soient toujours plus fiers d'être Français que fiers d'être musulmans.

'Our mission will be difficult, it will take time, it will be demanding for everyone. This will make French Muslims be prouder to be French than proud to be Muslims'.

This statement has attracted debate in the French community: Is it possible to ask Muslims to "less proud" of their religion and requires them to be loyal to the Republic of France? EM's statement implies a doubt about the ability of immigrants, especially Muslim immigrants, to assimilate into and integrate with French society.

The opposition candidate and his party, MLP and the FN party, considered as part of the opposition often criticized the policies of LaRem and PS. The most prominent programs of the FN party, under the leadership of MLP, is an ultra-nationalist program, which links antiimmigration and anti-terrorism. The program includes anti-immigration law and order issues; priority housing; social security; employment for the citizens of France; a competitive advantage for French companies; and imposing high taxes on companies that employ nonFrench nationals. The anti-terrorist program also tighter passport controls in the Schengen area; restrictions on immigration; expulsion of every immigrant convicted of a terrorist offense; increasing the number of prisons, reimposing the death sentence; and, increasing the number of police personnel (Hewlett, 2017).
According to this far right-wing political party, religion having caused changes in French society today and, since 2001, the assumption being it is targeteting Muslims. Some of the far right-wing parties have denounced immigration from Muslim countries with claims to wanting to "defend Europe's Christian civilization" against the Islamic threat. MLP, through his party, is trying to recast the argument by project a modern image of herself as a "defender of secularism and integration of the Republic". The defense is based on the rationale for restoring the Christian roots of French society and legitimizing anti-immigration policies (Scrinzi, 2017a). In an interview on TF1 television channel on 12 September 2016 MLP said:

Est-ce que l'islam est compatible avec la République: c'est au musulmans de répondre. Je crois que oui. Un islam tel que nous l'avons connu, laïcisé, oui. [...].Je ne définis pas la France par une couleur de peau. Ce qui est important c'est le sentiment d'appartenance à la nation française

'Is Islam compatible with the Republic: it is up to Muslims to answer. I think so. An Islam as we have known it, secularized it, yes. [...]. I don't define France by a skin color. What is important is the feeling of belonging to the French nation.'

Thus, according to MLP, FN policy does not aim to discriminate, but to defend the interests of all French citizens, regardless of their origin and their religion or their parents. Given these ideological perspectives of EM and MLP on secularism and Islam, then how are they manifested in their campaign speeches?

\section{Islam and Secularism in the Presidential Campaign 2017}

The rise of the Islamic community in the political sphere has begun to be seen in various countries. For example, in Indonesia it occured during the 2019 presidential election campaigns of Joko Widodo and Prabowo Subianto. Various media reported that both candidates played identity narratives in their campaign discourses; Prabowo was constructing religious narratives while Joko Widodo was constructing secular narratives (Nurita, 2019, Ayuwuragil, 2018). Debates about the concept of national identity, that developed into identity politics, also took place in the United States during the 2016 presidential election campaigns of Donald Trump and Hillary Clinton. Donald Trump's racism and xenophobic, self-casting himself as a "protector" of American society, was hit by an identity crisis and anxiety about the 
presence of Muslim immigrants, Mexican immigrants, and others from other countries (Parker, 2019). In the Netherlands nationalist and populist parties that adhered to anti-Muslim, anti-immigrant and anti-EU principles, such as the "Partij voor Vrijheid en Democratie" (PVD) Party led by Geert Wilder, also attracted votes in the 2017 parliamentary elections. These political events showed that identity in a discourse and action can be used to bring down, support, protect, and attack political parties, national ideologies, governments and either national or international organizations.

In addition, there was a fear of the rise of Muslim communities in Europe, the growing terrorist incident and the rise of fundamentalist Islam in the suburbs of France, had been leading politicians and the media began to construct a political discourse about Islam, including the representation of Islam and the national identity. The visibility of this discourse is also present in the discourse of presidential candidates on the campaign trail of EM and MLP in 2017. As discussed earlier, both candidates have different viewpoints when representing their concepts of Islam and national identity. This was because both have different political ideologies; EM has a centrist ideology while MLP has a right-wing ideology. Based on these ideological schemas, what were the lingual forms used by EM and MLP to represent Islam and secularism? And how did EM and MLP construct representations of Muslims in France?

\section{Lingual Construction of Islam and Secularism in Emmanuel Macron's and Marine Le Pen's Political Discourses}

The political discourses, conveyed by the presidential candidates, contains the views of candidates on problem faced by contemporary society. These discourses are aimed at the entire community, with the goal of creating a positive image of a presidential candidate. In the interaction between the presidential candidates and the people, the discourses function as an instrument of political communication that directly influences the voters' views. The data extracted from the speech discourses of EM and MLP shows secularism and Islam are found in all 12 public campaign speeches (six speeches from each candidate). The campaign speeches selected for analysis were those containing the concept of French national identity. These speeches were: EM's speeches in Mutualité (12 July 2016), Paris (23 April 2017 and 14 May 2017), Orléans (8 May 2016), London (21 February 2017), Mayotte (26 March 2016); and, MLP's speeches in Paris (1 May 2016, 9 November 2016, and 4 January
2017), Marseille (19 April 2017 and 23 April 2017) and Lyon (5 February 2017).

When discussing Islam in these lingual forms, Islam can be associated with the concept of its religion, ideology, followers, as well as its identities. For example, in the political discourse in Indonesia, Islam is often related to several identities, among which are progressive Islam, conservative Islam, and reactionary Islam. These identities are marked by their attitudes towards and perspectives on religious pluralism, liberalism, and secularism (Beck, 2016). Therefore, the terms 'radical', 'right wing', 'extremist', and 'religious fascist' frequently appear in political discourses on Islam in Indonesia. In the discourses presented by EM and MLP, Islam is related to the religion, Muslims, jihad, Islamic fundamentalists, the veil, and secularism. Table 1 shows the percentage of text from the 12 discourses about Islam.

'Islam' in EM's speech in Mutualité dated July 12, 2016 had a positive meaning because it was used to explain that the French do not have a fight with Islam, but with jihadists and Daesh (ad-dawla al-Islamiyya or ISIS): Nous avons un ennemi, une menace, les djihadistes, Daesh, mais ce n'est pas l'islam 'We have enemies, threats, jihadists and Daesh, but they are not Islam' (Saurel, 2016b). The use of the formula of negation in the sentence, ce n'est pas l'islam 'not Islam' is a descriptive negation, which aims to produce a certain effect, that changed the situation of interlocutionIn this context, "not Islam" is to emphasize that "Islam is not the enemy of the French people". EM's statement appears to counter Manuel Valls's proposal (Prime Minister of France in 2014 to 2016) for a ban on the wearing of headscarfs at universities. In addition, EM's speech in Mutualité was EM's first public speech as a part of LaRem's political movement. EM used this public meeting to express his criticisms against the government and to showcase his ambition to run for president. In this speech EM sought support from various parties or groups, including Muslims in France.

In keeping with his speech in Mutualité, EM expressed his views about Islam in his speech in London on 21 February 2017 to French citizens working in the city. On this occasion, EM reiterated that "Islam is not a problem" in a statement: $j$ 'ai dit "Tolerance zéro". Mais on peut être "Tolerance zéro", sans, pour autant, dire-mon problème, c'est l'the Islamic 'I would say zero tolerance rather than say my problem is Islam' (Macron, 2017c). EM states that there is no tolerance for anything that disrupts security, articulated as 'no tolerance' than to say "My problem is Islam". During the campaign, EM introduced the term tolerance zéro 'zero tolerance' 
Table 1. Islamic Coverage Text in EM and MLP Political Discourses. Source: constructed by the author from NVIVO analysis.

\begin{tabular}{|c|c|c|c|c|}
\hline \multirow{2}{*}{ No } & \multirow{2}{*}{ Lingual Form } & \multicolumn{2}{|c|}{ Coverage text } & \multirow{2}{*}{ Campaign Discourse } \\
\hline & & EM & MLP & \\
\hline 1. & Islam & $\begin{array}{l}0.02 \% \\
0.01 \%\end{array}$ & $0.01 \%$ & $\begin{array}{l}\text { EM - Campaign Speech in Mutualité } \\
\text { EM - Speech in London } \\
\text { MLP - Campaign Speech in Lyon }\end{array}$ \\
\hline 2. & islamiste ('Islamist') & & $\begin{array}{l}0.05 \% \\
0.12 \% \\
0.03 \%\end{array}$ & $\begin{array}{l}\text { MLP - Campaign Speech celebrating Jeanne d'Arc in Orléans } \\
\text { MLP - Speech in Lyon } \\
\text { MLP - Speech in Marseille }\end{array}$ \\
\hline 5. & $\begin{array}{l}\text { Musulman (s/es) } \\
\text { 'muslim(s)' }\end{array}$ & $0.01 \%$ & $0.01 \%$ & $\begin{array}{l}\text { EM - Campaign Speech in Mutualité } \\
\text { MLP - Campaign Speech celebrating Jeanne d'Arc in Orléans } \\
\text { MLP - Speech in Marseille }\end{array}$ \\
\hline 3. & $\begin{array}{l}\text { Islamophobie } \\
\text { ('Islamophobia') }\end{array}$ & & $0.02 \%$ & MLP - Campaign Speech in Lyon \\
\hline 4. & $\begin{array}{l}\text { Islamo-gauchiste } \\
\text { ('Islamic leftist') }\end{array}$ & & $0.03 \%$ & MLP - Campaign Speech in Lyon \\
\hline 6. & $\begin{array}{l}\text { Djihadiste } \\
\text { 'Jihadist' }\end{array}$ & $0.01 \%$ & $0.02 \%$ & $\begin{array}{l}\text { EM - Campaign Speech in Mutualité } \\
\text { MLP - Campaign Speech in Paris }\end{array}$ \\
\hline 7. & $\begin{array}{l}\text { Fondamentalisme } \\
\text { Islamiste } \\
\text { 'Islamic Fundamentalist' }\end{array}$ & & $\begin{array}{l}0.12 \% \\
0.34 \% \\
0.08 \%\end{array}$ & $\begin{array}{l}\text { MLP - Campaign Speech celebrating Jeanne d'Arc in Orléans } \\
\text { MLP - Speech in Marseille } \\
\text { MLP - Speech in Lyon }\end{array}$ \\
\hline 8. & $\begin{array}{l}\text { Voile } \\
\text { 'Veil' }\end{array}$ & & $\begin{array}{l}0.01 \% \\
0.01 \% \\
0.01 \% \\
\end{array}$ & $\begin{array}{l}\text { MLP - Campaign Speech celebrating Jeanne d'Arc in Orléans } \\
\text { MLP - Campaign Speech in Paris } \\
\text { MLP - Speech in Marseille }\end{array}$ \\
\hline 9. & $\begin{array}{l}\text { Laicité } \\
\text { 'Secularism' }\end{array}$ & $\begin{array}{l}0.05 \% \\
0.01 \% \\
0.05 \%\end{array}$ & $\begin{array}{l}0.01 \% \\
0.02 \% \\
0.01 \%\end{array}$ & $\begin{array}{l}\text { EM - Campaign Speech in Mutualité } \\
\text { EM - Speech in London } \\
\text { EM - Presidential Victory Speech } \\
\text { MLP - Campaign Speech celebrating Jeanne d'Arc in Orléans } \\
\text { MLP - Speech in Lyon } \\
\text { MLP - Speech in Marseille }\end{array}$ \\
\hline
\end{tabular}

to criticize the government's passivity in dealing with criminality. In an effort to achieve tolerance zéro EM planned to increase the number of police officers and military police personnel.

Unlike EM's statement, in a speech in Lyon on February 5, 2017, MLP related the lingual form of "Islam" with Islam radicalisé 'radicalized Islam' in a statement: Islam radicalisé, c'est-à-dire de l'idéologie du tout religieux 'radicalized Islam, that is to say the ideology of the whole religion' (Pen, 2017b). MLP's speech in Lyon was the grand discours de MLP because in this speech MLP delivered his policies, especially those related to security including immigrant issues, terrorism, and radical Islam. In this context, MLP viewed Islam as a threat to France. He stated that there are two aspects of globalization which threatened France, namely mondialisme financer 'financial globalization' and mondialisme djihadiste 'jihadist globalization'. Both are based on two ideologies, namely idéologie de tout commerce 'ideology which is intended for trading' and idéologie de tout religieux 'ideology of the whole religion'. The word 'Islam', in MLP's speech, is coupled the suffixes '-iste' and '-isme', to express the ideology of Islamism (-isme) 'extreme Islam or radical Islam', and islamiste (-iste) or fondamentalisme islamiste (Islamist fundamentalism) 'Islamist fundamentalism'. Both the derivation '-isme' and '-iste' are closely linked to terrorism.

Regarding the form islamiste 'an advocate or supporter of Islamic militancy or fundamentalism' and musulman 'Muslim', both have two different meanings. Islamiste means the organization that implements the ideology of Islamism, the ideology which advocates the concept of Islam in the government of a country by applying the sharia as the basic law (Fathi 2009), whereas in the Larousse dictionary musulman refers to Muslim followers of the Prophet Muhammad SAW. Similar to the meaning of Islamism in French, the term Islamism in Indonesia is understood as Islamic ideology that tends to 
Table 2. Islamiste lingual form relation in MLP's campaign discourse. Source: constructed by the author from NVIVO analysis.

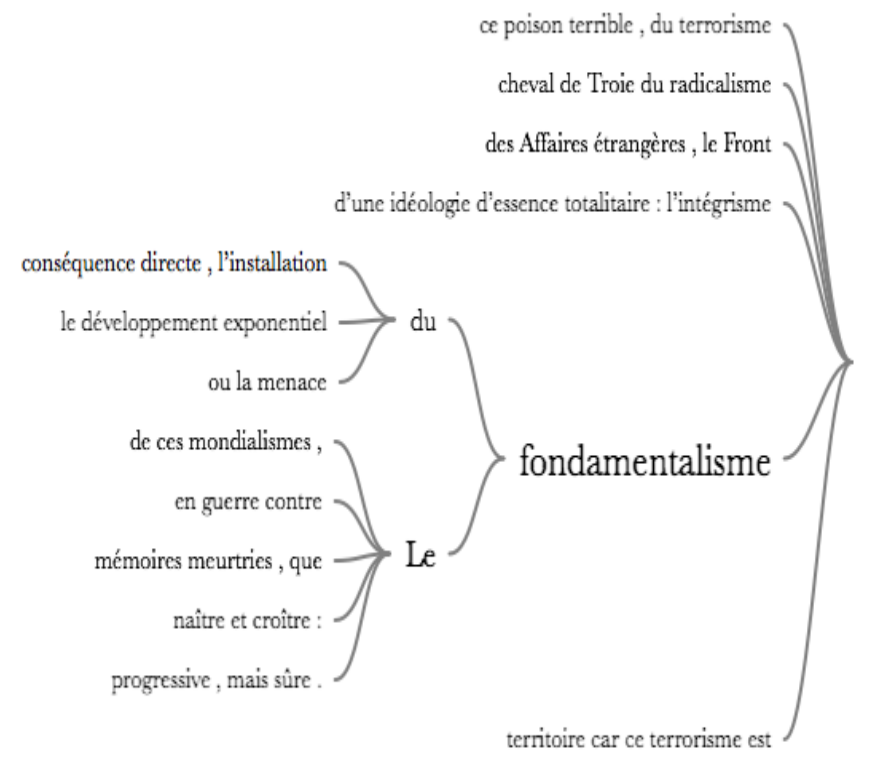

be radical and not liberal; antagonistic to non-Moslems, and self-isolating from the world (Fealy \& White, 2008). In the 2017 presidential election in France, EM and MLP both used the word musulman (respectively $0.01 \%$ ) in their campaign discourses. However, for the word islamiste, only MLP used it $(0.05 \%, 0.12 \%, 0.03 \%$, in the three campaign discourses).

In Table 2 the word islamiste 'islamist' is correlated with the word fondamentalisme 'fundamentalism', intégrisme islamiste 'Islamist fundamentalism', radicalisme 'radicalism', terrorisme 'terrorism', menace 'threat', barbare 'savage', agresser 'to attack'. All the words are joined to the word islamiste and have a negative value. MLP uses islamiste to describe radical Islam, the perpetrators of terrorism, and the immigrants who are considered affiliated with radical Islam. Statements by MLP are in line with his campaign program that is antiimmigration linked to terrorism.

The lingual form islamophobie 'islamopobia' and islamogauchiste or Islamo-gauchisme 'Islamist left-wing movement'. Islamophobie is a phenomenon of fear and hatred of Islam and all things associated with it, especially Muslims, mosques, the Qur'an, and the burqa. Islamogauchiste is a term that refers to the current revival of Islam and Islamism thought and is also considered as a reaction to replace the classic proletarian class struggle. Members of this religious obscurantist form are mostly non-Muslims (Julliard, 2018). Both these words $(0.02 \%$ and $0.03 \%$ ) were used by MLP in a campaign speech in

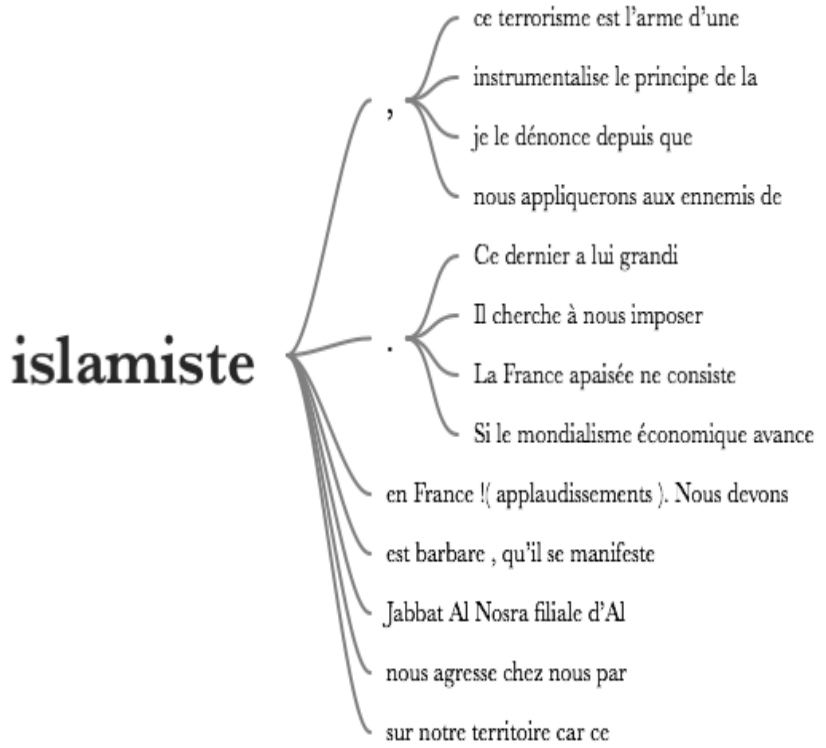

Lyon to explain the rise of radical Islam which, among others, were carried out by anti-French Islamo-gauchiste.

In addition to the ideology and its adherents, "Islam" is also related by lingual markers, such as the voile 'veil'. Voile lingual form is mentioned several times in MLP's speech (equal to $0.03 \%$ in three campaign speeches). Why was it an issue for MLP? Because the veil is considered by the MLP as a restraint on the dignity and freedom of women. In the opinion of Larzillière \& Sal (2011), MLP seeks to mobilize the pseudo-feminists to increase support for the presidential election and also to legitimize anti-immigration politics. In this context, feminism is used as a metaphor for racism or sexism racialization (Scrinzi, 2017b; Tevanian, 2007). In other words, the issue of women's rights is adapted to reframe anti-immigration politics in the context of multiculturalism and hostility against Muslims.

Furthermore, the lingual forms of laïcité, or secularism, EM said in positive sense, among others la läicité protege des identités fermées 'secularism is a protector of exclusive identites', la laïcité n'est pas un mot date 'secularism not a dated word', pas un combat de la lä̈cité contre une religion 'secularism is not against religion', la laïcité républicaine sera défendue 'republican secularism will be defended'. These forms are presented in the table 3 .

In contrast, MLP associates laïcité with the state or anything negative, among others, with histoire tragique 'tragic history', les Débats sur l'immigration 'debate 
Table 3. Laïcité 'secularism' lingual form relation in EM's speeches. Source: constructed by the author from NVIVO analysis.

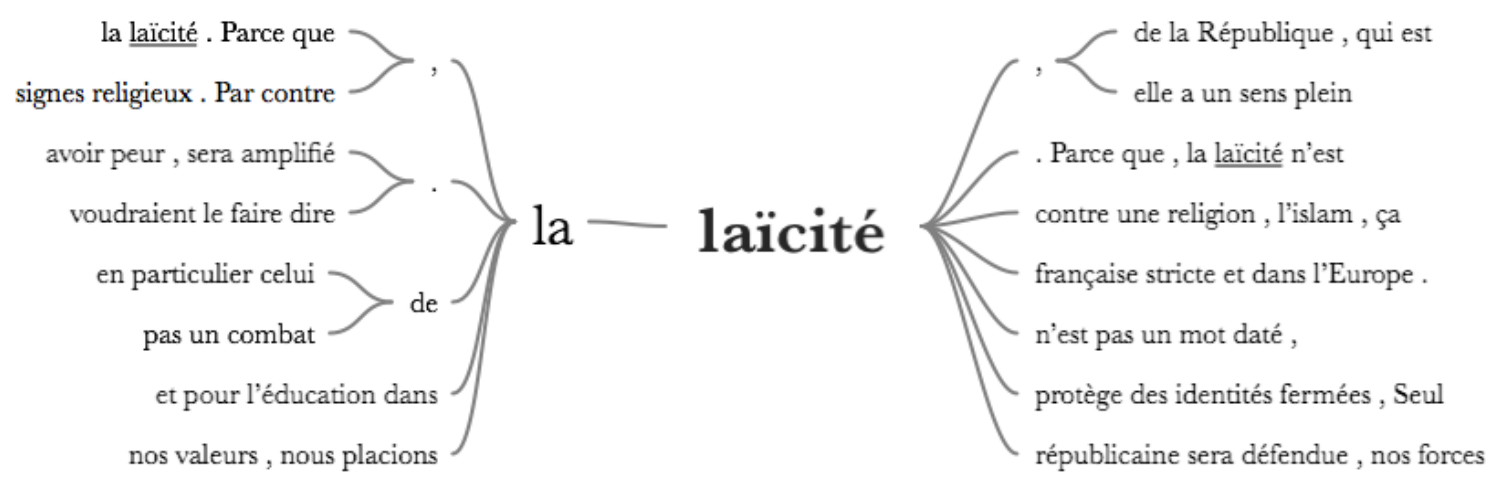

Table 4. Laïcité ‘secularism' lingual form relation in MLP speech. Source: constructed by the author from NVIVO analysis.

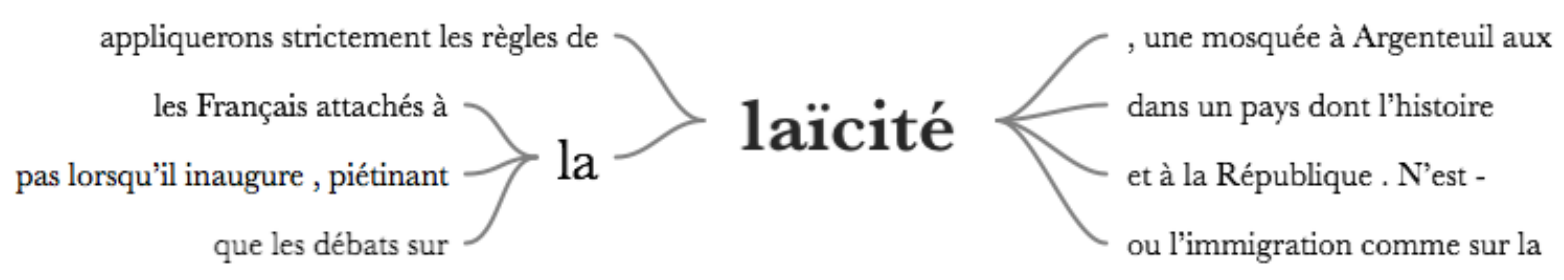

about immigration', piétinant la laïcité 'trampling on secularism' as shown in the word-tree in table 4 above.

In MLP's campaign speeches, Laïcité, or secularism is used as a tool to retake France from the rise of Islamism in Europe. For MLP, secularism is used as a medium to restore French national identity.

Given the different lingual forms of Islam found in both EM and MLP speeches, how then do they influence public opinion?

\section{Emmanuel Macron and Marine Le Pen reflections on Islam}

Through their political discourses, EM and MLP manifest their ideas in the language of their own choosing. They organize information in the discourses based on communication strategies to support their arguments, to convince the audience, and finally to shape public opinion. The audience, who were directly involved in discourse interactive, might participate the meaning they attach to it in the French political context. How did EM and MLP represent Islam in the discourse of the campaign? The following is the analysis of the representation of Islam in the data from the presidential campaign in 2017, based on the perspectives of EM and MLP.

\section{a) Islam and Religion}

EM in some campaign speeches represents Islam as a religion that exist in France. In his speech at Mutualité dated July 12, 2016, EM expressed disapproval of the statement of Manuel Valls (PM France 2016) concerning secularity. Firstly, Valls stated that radical Islamism is an ennemi 'enemy'. The statement was uttered by Valls in the Assemble Nationale after the terrorist attacks in Paris late 2015 (Andraoui, 2017):

Oui, nous avons un ennemi, et il faut le nommer, c'est l'islamisme radical. Et un des éléments de l'islamisme radical, c'est le salafisme

'Yes, we have enemies, and it is radical Islamism. And one of the elements of radical Islamism is Salafism'.

In order to express disagreement with Valls' statement, EM confirms that the French Republic is against the jihadists and Daesh, not Islam. Therefore, it is not a battle between secularism and religion or Islam, but against radical Islam. In addition, EM also states that secularism is not a value that does not mean anything, but a value that aims to protect identite fermée 'closed identity', meaning the identity that allows each individual to identify 
themselves and their religion freely, but all must remain under the laws and regulations of the Republic of France. Secondly, EM expresses disapproval of the Manuel Valls' thoughts on possible legislation to ban the use of the headscarfs at university, stated as follows.

\section{Je ne crois pas, pour ma part, qu'il faille inventer de nouveaux textes, de nouvelles lois, normes, pour aller chasser le foulard à l'université, pour aller traquer dans les sorties scolaires celles et ceux qui peuvent avoir des signes religieux.}

'For me, it is not necessary to create new texts, new laws, standards, to go hunting headscarves in universities, to track down the people who wear religious signs at school events.

EM does not agree with the idea of a ban on headscarves in universities, but EM also states that France is a country that upholds the laws, norms, regulations and egalite or equality between men and women. It stems from the polemical use of the veil in 2003. At that time the President of France asked the commission on secularism led by Bernard Stasi to make laws banning the use of religious signs in the public services, including schools. Then, in 2004, the law was modified into Code de l'Education 'education regulations, prohibiting the use of religious symbols prominently among school students. In fact, these rules refer to secularism which is the reconstruction of religious freedom, but in fact tension arose due to the regulation, among others, the pressure on young girls from immigrant backgrounds who are forced by their community to wear headscarves in public schools (Sidibé et al., 2006).

\section{b) Islam and Security}

EM states that Islam is not the cause of the threat to security in France. In his speech in London on February 21, 2017, EM states: j'ai dit “Tolerance zéro". Mais on peut être "Tolerance zéro", sans, pour autant, dire mon problème, c'est l'the Islamic 'I say zero tolerance rather than say my problem is with Islam' (Macron, 2017c). In this context, EM explained that the cause of the current security threat is not Islam, but terrorists. In addition, according to EM, la sécurité, c'est la première des libertés 'security is paramount in liberty', meaning that French society is said to be 'free' if they feel safe and calm when they're in public spaces. For that, EM proposed the term of zéro tolerance to criticize the government's passivity in dealing with crime. EM found at this time police faced greater criminality in the districts and carried out the policy of "stop and go" (a policy to contain crime) which was ineffective. In order to overcome this, EM proposed the addition of 10,000 police personnel.

\section{c) Islam and Terrorism}

MLP states that Islamism is related to "terrorism". In his speech in Marseille, MLP declares that terrorism threatens the future of France (Pen, 2017a):

Ce poison qui ruine notre capacité à regarder l'avenir avec espérance, ce poison terrible, du terrorisme islamiste, je le dénonce depuis que j'ai lancé ma campagne

'This poison that damages our ability to look to the future with hope, this terrible poison, the terrorist of Islamism, I have denounced it since the beginning of my campaign'.

MLP's statement is a reaction to the French prime minister's statement saying that "the French younger generation get used to the threats and attacks of the terrorists". According to MLP, this statement shows that the French government is very weak, and it cannot be left unchallenged. In fact, MLP considered that President François Hollande did not dare issue a policy to address the terrorist threat. To that end, MLP proposed Schengen border controls be tightened and increase the number of officers working at the border. In addition, MLP proposed "cleansing" by expelling those who indicated signs of fanaticism and had $\mathrm{S}$ cards (individuals considered dangerous), purportedly located in the suburbs. According to the MLP, the ideology of fundamentalist Islamism is an ideology which is very dangerous because it can brainwash groups to carry out terrorist attacks.

\section{d) Islam and Immigrants}

MLP declared that Islam is synonymous with immigrants. According to MLP, immigrants who come to France legally or illegally are not serious about assimilating into French society. In a speech in Marseille, MLP took the examples of Muslim immigrant actions that work agains of assimilation, among others: to pray together in the way of Clichy; a ban on women visiting cafes; and, threats to female Muslims who refuse to wear the hijab and dare to wear skirts. To this end, MLP proposed to halt mass immigration: devons nous l'arrêter massive immigration pour le bien de tous 'we have to stop mass immigration for the benefit of all of us'. Indeed, anxiety over immigrants mainly arises in the FN party. Anxiety is evidenced by the alleged ghettoization in urban areas is seen as proof that France was not able to assimilate immigrants into its society immigrants. This anxiety 
increased with economic globalization which was causing an increase of unemployment. For this reason, the FN party declared a crisis of confidence in the political elite and forewarned the political demise of France.

Anti-immigration messages presented by MLP in the presidential campaign program is slightly different from the anti-immigration messages of her father, Jean Marie Le-Pen in the presidential campaign in 2007. In the 2007 campaign, anti-immigration and xenophobia become a central theme of FN's campaign program. All policies and other campaign programs pivoted on a central point, namely anti-immigration. Instead, in MLP's campaign platform of 2012 and 2017, anti-immigration was not a stand-alone issue, but rather found in the fabric of the party's social, economic, and political programs. Anti-immigration was linked to the unemployment rate, the level of purchasing power, social security, and the security situation. Thus, the anti-immigration platform does not appear as an end in itself, but as part of a holistic solution. If immigration could be reduced, then the social, economic, and political development of France would be better (Stockemer \& Barisione, 2017), as in the example of MLP's statement in a speech in Marseille on 19 April 2017 as follows.

Il reste un autre sujet, un autre sujet qui certes ne concerne pas que la sécurité mais qui concerne aussi la sécurité: c'est celui de l'immigration de masse, et il n'est pas difficile de comprendre le lien qu'il peut y avoir entre une immigration massive et une insécurité en augmentation.

'There is an other subject in addition to security, but related to security, that of mass immigration, and it is not difficult to understand the possible link between mass immigration and rising insecurity'.

In the above statement, MLP reframed immigration using populist rhetoric: le lien entre une massive immigration insécurité en et une augmentation 'the relationship between mass immigration and rising insecurity'. MLP, based on the ideological principles of the FN party, cast immigration, using simple and emotional rhetoric, as possibly linked with "increased insecurity". This populist tactic is characteristic of the right-wing populist party.

\section{e) Islam and French National Identity}

Demographic changes in France due to the increase of immigrants, mainly from North African countries and this social group's high birth rate, has meant a rapid increase in the Muslim population in France. French Muslims have become more active in the public space as a result of the Islamic awakening in the children and grandchildren of immigrants. This phenomenon has led to an "issues of identity" for some French citizens. This section of the population has become involved in a potential Islamization discourse and the discourse on the potential Islamisation of the French state. Laicité concept was re-emerged again in the midst of the debate about the "identity crisis".

In contrast to MLP's rhetoric and the "identity crisis", EM states that Islam is part of the French identity. This was stated in a speech at the Mutualité EM as follows (Saurel, 2016b):

Alors oui, nous avons une identité française, avec ses origines. Mais au milieu, il y a des athées, des catholiques, des protestants, des juifs, des musulmans, tous de l'identité française. C'est cela notre identité.

'Yes, we have a French identity, with its origins. But in the midst of us, there are atheists, Catholics, Protestants, Jews, Muslims, all of French identity. This is our identity'.

EM as discussed above, sees laïcité, or secularism, to mean France is not against Islam, but rather against radical Islamists. However, the most important aspect of all is the individual who lives in France who is required to adhere to the concept of laïcite in the French Republic. Applying laicité means upholding the French national identity. According to EM in his speech, laïcité is the basis of freedom of religion. Indeed, France came from Christianity, but in the presence of French laïcité all citizens are free to embrace their own religion. All religions, whether Christianity, Catholicism, Islam and atheism, are a part of French identity in the Republic of France.

In contrast, MLP declares that Islam threatens France's national identity. MLP sees Islam as a threat to laïcité and threatens the concept of identity in the French Republic. Laïcité is used as a basic premise of the Republicans that has been used by MLP for an antiIslamic discourse that is used to attract prospective voters in the presidential campaign. In a speech in Marseille, MLP said:

La mondialisation et son corollaire l'immigration minent notre pays. Je n'ai pas peur de le dire, nous sommes tout d'abord sous la menace d'une dilution de notre identité nationale [..]. Allonsnous sérieusement accepter de voir notre unité nationale voler en éclats, avec l'émergence d'une société fragmenté en communauté. 
'Globalization and immigration are ruining our country. I'm not afraid to say it, because we are under the threat of weakening national identity [...]. Should we accept seeing the destruction of our national unity, with the emergence of fragmented society.'

For decades, Muslims have become more visible in Western countries. Especially after the attacks of 11 September 2001, followed by a series of terrorist attacks in Europe from the early 2000s, Islam emerged in discourses related to security and religious radicalization. In addition, the mass media has also framed the news about the emergence of fundamentalist Islam in the immigrant community in the suburbs of France. Islam in these communities was identified by MLP as one cause leading to the loss of the French national identity. As noted above, for MLP, immigration threatens France national identity.

From this analysis, it can be seen that EM and MLP conceptualise "Islam" in accordance with their different party ideologies and in the context of seeking electoral victory. The discourse on "Islam" itself cannot be separated from the principles found in the French concept of laïcité, a principle which has been interpreted from different viewpoints by EM and MLP.

\section{CONCLUSION}

The discourses on secularism by MLP and EM show differences in viewpoints. MLP sees secularism in France as being under threat because there are external threats, coming from immigrants, especially Muslim immigrants. This was evidenced by the use of lingual forms associated with the concepts of 'Islam' and 'immigrant', for example islamophobie 'islamopobia' and islamogauchiste or Islamo-gauchisme 'Islamist left-wing movement'. The situation resulted in MLP seeking to restore France to its past glory with its Christian cultural heritage. The arrival of these immigrants, according to the MLP caused, among other things, terrorism, insecurity, and economic and social problems, such as unemployment. In the face of this situation, MLP projected herself as the defender of the French people. MLP's concept of securalism was leaned towards towards protectiveness and exclusiveness. MLP's language shows that she saw immigrants as part of an entity which is outside of the French identity (the others). Not only immigrants, but Muslims who had became citizens of France became a part of this other entity.

Conversely, EM conceived secularism as a concept to support and protect the identity of the French nation. EM considered that the arrival of immigrants from different foreign cultures as adding to the variety in the culture and identity of France. This was indicated by the lingual forms such as la laïcité protégé des identités fermées 'secularism protects closed identity', la laïcité n'est pas un mot date 'secularism is not an outdated word'. Secularism was used as a guarantee of the freedom of individuals to carry out their religious practices in private. Thus, according to EM secularism was one of acceptance that is, EM views migrants and Muslims as part of the community.

The discourse on secularism of the presidential candidates contains different points of view. MLP focuses more on the interests of French citizens internally, while EM places more emphasis on the interests that are external or mondial 'global'. While MLP and EM both show different views concerning secularism, both candidates demonstrated similar positions in rejecting fundamentalist Islam and terrorism. Opposing views are typical in a presidential campaign, including in Indonesia. In the presidential election in 2019, Joko Widodo and Prabowo expressed their views concerning religion and the country differently. Jokowi often expressed Islamic discourse as a cultural moderate, while Prabowo tended to express ideological conservativism. In such campaigns, the delivery of political narratives by presidential candidates serves as a vehicle to win support from different sections of the ideological spectrum within society.

The concept of secularism in this research has focussed on the analysis of discourse production in the two candidates' respective campaign speeches. The concept of secularism in France, however, is also presented and debated more widely by the French, both in the mass media and social media. This study has enabled an analysis of French political discourse at a national political level in the context of seeking a political mandate on issues such as secularism and its relationship with Islam.

\section{REFERENCES}

Akan, M. (2009). Laïcité and multiculturalism: The Stasi Report in context. British Journal of Sociology, 60(2), 237-256. https://doi.org/10.1111/j.14684446.2009.01229.x

Allen, C. (2011). Islamophobia. Ashgate.

Atabong, N. N. (2018). Immigration and the Revival of Nationalist Sentiments in France: A Nationalistic Rhetoric of Marine Le Pen. Department of Social Sciences and Philosophy University ofJyväskylä.

Ayuwuragil, K. (2018). Ma'ruf Amin, Bantalan Jokowi untuk Politik Identitas. CNN Indonesia. https://www.cnnindonesia.com/nasion 
al/20180809215908-32-321070/maruf-aminbantalan-jokowi-untuk-politik-identitas

Barton, G. (2010). Indonesia: legitimacy, Secular democracy, and Islam. Politics and Policy. https:// doi.org/10.1111/j.1747-1346.2010.00244.x

Baubérot, J. (2012a). French Secularism : Republican, Indivisible, Democratic and Social. Cités, 4(52), 11-20.

Baubérot, J. (2012b). La laïcité falsifiée. La Découverte.

Baubérot, J. (2015). Sécularisation, sécularisme, laïcité dans une perspective sociologique/ Secularization, secularism, laicity in a sociological perspective. In Penser global: internationalisation et globalisation des sciences humaines et sociales.

BBC. (2015). Charlie Hebdo attack: Three days of terror. BBC News.

Beck, H. L. (2016). Islam in Indonesia. The Contest for Society, Ideas and Values, written by Carool Kersten. Bijdragen tot de taal-, land-en volkenkunde / Journal of the Humanities and Social Sciences of Southeast Asia, 172(4), 571-572. https://doi. org/10.1163/22134379-17204016

Betz, H.-G. (2004). La droite populiste en Europe. Extrême et démocrate? CEVIPOV.

Blanchot-Isola, C. (2017). Le défenseur des droits. Revue Sage - Femme. https://doi.org/10.1016/j. sagf.2017.09.001

Bowen, J. R. (2009). Recognising Islam in France after 9/11. Journal of Ethnic and Migration Studies, 35(3), 439-452.

Bugeau, C. (2017, Juli 8). 'En marche . . vers un parti unique. 'http://http//www. agoravox.fr/tribune-libre/ article/en-marche-vers-un-parti-unique-193304

Casanova, J. (2009). The Secular and Secularisms. Social Research, 764(The Religious-Secular Divide), 1049 1066.

Chevrier, G. (2007). La laïcité, un choix résolu de sens de l'histoire. http://http// ripostelaique.com/ La-laiciteun-choix-resolu-de-sens.html.

Davidson, M. del G. (2018). Black women's bodies, ideology, and the public curriculum of the pro- and anti-choice movements in the US. Gender and Education. https:// doi.org/10.1080/09540253.2016.1225011

Davidson, N. (2012). Only Muslim, Embodying Islam in Twentieth-Century France. Cornell University Press.

Delaurens, D. (2018). En Marche, La Politique Moderne? Esprit, 4, 11-17. https://doi.org/DOI 10.3917/ espri.1804.0011

Dennison, J., \& Talò, T. (2017). Explaining attitudes to immigration in France. In European University Institute Robert Schuman Centre for Advanced Studies Migration Policy Centre.

Doyle, N. J. (2011). Lessons from France: popularist anxiety and veiled fears of Islam. Islam and Christian-
Muslim Relations, 22(4), 475-486.

Dragvigny, J. (2017). Présidence Macron et Immigration: La Continuité en Marche. Migrations Société, 2(168), $3-11$.

Dungan, N. (2018). Far-right politics in Europe. International Affairs. https://doi.org/10.1093/ia/iix266

Duverger, M. (1951). Les Partis Politiques. Librairie Armand Colin.

Duverger, M. (1964). L'éternel marais. Essai sur le centrisme français. Revue Française De Science Politique, 14(1), 33-51.

Duverger, M. (1965). Le bipartisme est-il possible en France? Association française de science politique.

Duverger, M. (1967). La démocratie sans le peuple. Seuil.

Elgie, R. (2018). The election of Emmanuel Macron and the new French party system: a return to the éternel marais? Modern \& Contemporary France, 26(1), 15-29.

Elson, R. E. (2010). Nationalism, Islam, "secularism” and the state in contemporary Indonesia. Australian Journal of International Affairs. https://doi. org/10.1080/10357711003736493

Fealy, G., \& White, S. (2008). Expressing Islam: Religious life and politics in Indonesia. Expressing Islam: Religious Life and Politics in Indonesia, 89(April), $1-295$.

Forsdick, C. (2018). Postcolonial Counterpoint: Orientalism, France and the Maghreb by Farid Laroussi . University of Toronto Quarterly. https://doi.org/10.3138/ utq.87.3.29

Gorce, B. (2017). Emmanuel Macron et Marine Le Pen, deux conceptions de la laïcité. La Croix.

Hewlett, N. (2017). The phantom revolution. The presidential and parliamentary elections of 2017. Modern \& Contemporary France, 25(4), 377-390. https://doi. org/DOI: 10.1080/09639489.2017.1375643

Joppke, C. (2009). Veil: mirror of identity. Polity Press.

Julliard, J. (2018). L'Islamo-Gauchisme, C'est la Haine de l'Identité Française.

Kastoryano, R., \& Upreti, B. C. (2006). Nationalism In South Asia: Trends and Interpretation. The Indian Journal of Political Science, 67(3), 535-544. https:// doi.org/10.1111/j.1747-7379.2004.tb00234.x

Koopmans, R. (2005). Migrants between Transnationalism and National Citizenship. In Contested Citizenship: Immigration and Cultural Diversity in Europe.

Kuru, A. T. (2008). Secularism, State Policies, and Muslims in Europe: Analyzing French Exceptionalism. Comparative Politics, 41(1), 1-19. https://doi. org/10.2307/20434102

Lægaard, S. (2017). Multiculturalism and secularism: Theoretical understandings and possible conflicts. Ethnicities. https://doi. org/10.1177/1468796817690779 
Lamine, A.-S. (2006). Les foulards et la République. Revue des Sciences sociales.

Larzillière, C., \& Sal, L. (2011). Comprendre l'instrumentalisation du féminisme à des fins racistes pour resister. In Contretemps. http:// www.contretemps.eu/interventions/comprendreinstrumentalisation-féminisme-fins- racistes-résister

Laurence, J., \& Vaisse, J. (2006). Integrating Islam: political and religious challenges in contem-porary France. Brooking Institution Press.

Lesselier, C. (1997). De la Vierge Marie à Jeanne d'Arc. L'extrême droite frontiste et catholique et les femmes. 1984-1990. In L'Extrême Droite et les Femmes (hal. 41-70). Golias.

Macron, E. (2016). Discours à Orléans. 1-7.

Macron, E. (2017a). La France En Marche! 1-16.

Macron, E. (2017b). Rassemblement à Mayotte. 1-5.

Macron, E. (Ed.). (2017c). Rassemblent de Londres.

Mc Dougall, J. (2018). Laïcité, sociologie et histoire contemporaine de l'islam. Annales: Histoire, Sciences Sociales, 73(2), 411-439. https://doi. org/10.1017/ahss.2019.6

Messina, A. M. (2006). Muslims and the State in Britain, France, and Germany. Perspectives on Politics. https://doi.org/10.1017/s153759270667014x

Modood, T. (2010). Moderate secularism, religion as identity and respect for religion. Political Quarterly. https:// doi.org/10.1111/j.1467-923X.2010.02075.x

Munif, Y. A. (2011). French Postcolonial Nationalism and Afro-French Subjectivities. Graduate School of the University of Massachusetts.

Nillson, P.-E. (2015). 'Secular Retaliation': A Case Study of Integralist Populism, Anti-Muslim Discourse, and (Il)liberal Discourse on Secularism in Contemporary France. Politics, Religion \& Ideology, 16(1), 87-106.

Njoto-Feillard, G. (2015). Religious Pluralism and Tolerance in Jokowi's Indonesia. 1-8.

Nurita, D. (2019). TKN Jokowi: Kampanye Akbar Prabowo Kental Politik Identitas. Tempo. https://pilpres.tempo. co/read/1193232/tkn-jokowi-kampanye-akbarprabowo-kental-politik-identitas

Pen, M. Le. (2017a). 2017-04-19 discours de Marine Le Pen à Marseille Grand Meeting.

Pen, M. Le. (2017b). Grand discours - programme de Marine Le Pen le 5 février 2017 à Lyon.

Portier, P. (2018). Le tournant substantialiste de la laïcité française. Horizontes Antropológicos. https://doi. org/10.1590/s0104-71832018000300002

Power, T. P. (2018). Jokowi's authoritarian turn and Indonesia's democratic decline. Bulletin of Indonesian Economic Studies. https://doi.org/10.1 080/00074918.2018.1549918

Raymond, G. G. (2009). From Islam en France to Islam de France: contradictions of the French left's responses to Islam. Patterns of Prejudice, 43(5), 481-496.

Reynié, D. (2016). "Heritage populism" and France's national front. Journal of Democracy. https://doi. org/10.1353/jod.2016.0061

Saurel, P. (2016a). Discours d'Emmanuel Macron Montpellier. 1-15.

Saurel, P. (2016b). Discours d'Emmanuel Macron Mutualité. 1-15.

Scrinzi, F. (2017a). A "New" National Front? Gender, Religion, Secularism and the French Populist Radical Right. Gender and Far Right Politics in Europe, 127-140.

Scrinzi, F. (2017b). Gender And Women In The Front National Discourse And Policy: From 'Mothers Of The Nation' To 'Working Mothers'? Journal New Formation, 91, 87-101.

Sidibé, A. S., Badji, M., Mboda, E.-M., \& Otis, G. (2006). Genre, Inégalités et Religion. In Aspect de l'Etat de Droit et Démocratie (Agence Uni). Editions des archives contemporaines.

Silverman, M. (1992). Deconstructing the Nation: Immigration, Racism and Citizenship in Modern France. Routledge.

Spickard, J. V. (2013). Rethinking Secularism. Journal of Contemporary Religion. https://doi.org/10.1080/13 537903.2013.750853

Stockemer, D., \& Barisione, M. (2017). The 'new' discourse of the Front National under Marine Le Pen: A slight change with a big impact. European Journal of Communication, 1-16.

Teitgen-Colly, C. (2011). La Commission Nationale Consultative des droits de l'homme et la Création du Défenseur des droits. Revue Francaise d'Administration Publique. https://doi.org/10.3917/ rfap.139.0409

Tevanian, P. (2007). La République du mépris. Les métamorphoses du racisme dans la France des années Sarkozy. La Découverte.

Triandafyllidou, A. (2011). Addressing Cultural, Ethnic \& Religious Diversity Challenges in Europe. AcceptPluralism.Eu.

Udasmoro, W. (2017). The language construction of Muslims as the others in French contemporary discourses. Indonesian Journal of Islam and Muslim Societies, 7(1), 77-99. https://doi.org/DOI:10.18326/ijims. v7i1.77-99

Vasilopoulos, P., Marcus, G. E., \& Foucault, M. (2018). Emotional Responses to the Charlie Hebdo Attacks: Addressing the Authoritarianism Puzzle. Political Psychology. https://doi.org/10.1111/pops.12439

Weber, H. (2017). Les bases de La République en Marche, «parti entreprise». Libération.

Werbner, P. (2007). Veiled Interventions in Pure Space. Theory, Culture \& Society. https://doi. 
org/10.1177/0263276407075004

Wessler, H., Rinke, E. M., \& Löb, C. (2016). Should We Be Charlie? A Deliberative Take on Religion and
Secularism in Mediated Public Spheres. Journal of Communication. https://doi.org/10.1111/jcom.12213 